\title{
Schools and Implementation of Innovations as Active Element in Practice
}

\author{
Fatmir Agaj \\ PhD candidate at European University of Tirana \\ Email: fatmiragaj1@hotmail.com
}

\section{Doi:10.5901/jesr.2014.v4n2p51}

\begin{abstract}
This paper interlocks methods and forms of contemporary work in organizing learning from teachers with innovations in teaching behaviours that stimulate learner sense of active participation in learning, developing critical thinking, analysis and action for quality and effective learning. Innovations in the learning process, have a very important role in enriching the learning experiences, therefore, these activities help students to motivate, increase knowledge, skills, attitudes, values, and awakens interest for discussion. The purpose of this paper was to give an overview of the existing implementation of innovations in our educational institutions by teachers and to assess how teachers are aware of the role and importance of innovation in the learning process. Survey research questions were: Are the innovations applied in educational institutions by teachers, and how their application affects the creative activist and personality development of students? We used some of the basic methods through which we have researched this problem quite significantly in primary education institutions of Kamenica and the technique that is applied was that of the survey through a questionnaire for teachers. The research sample consisted of 100 teachers of urban and rural schools, such as two middle schools from urban of the Kamenica town, three from the rural municipality of Kamenica, Kosovo. From the survey results, we have concluded that the primary schools in the municipality of Kamenica little work in this direction despite the fact that a number of teachers have been trained, but they are all making efforts to implement innovations in the learning process. Teachers were of the opinion that to implement innovations in teaching technical, material conditions are needed and that teachers are aware of their importance and the positive effects they bring to the student. Recommendations from this study will probably raise the awareness of all participants of the school life and to contribute to comprehensive discussion that is being developed for education reform in our country, in taking initiatives for systematic implementation of innovations in teaching where beneficiaries will be the students, education in general and society.
\end{abstract}

KeyWords: education institutes, innovation, implementation, teachers

\section{Introduction}

"The main purpose of education is to create people who are capable of doing new things, not simply repeating what other generations have done- people who are creative, inventive and discoverers. The second goal of education is to form minds which can be critical, to verify and not to accept anything that is provided to them."1

In this paper we treat the problem about implementing innovations in learning by educational institutions, to give innovations greater importance in teaching, and to prove the organization way of educational institutions in their implementation in practice.

Seeing that educational institutions are among the major factors that can rightfully influence in persuading teachers in the implementation of innovations in teaching, then we have shown the idea to destine to these institutions in doing something more in this direction .

This paper was accessed, by reason that, as from within and outside our educational institutions we are surrounded by multiple types of innovations, but, nevertheless institutions act as deaf and almost they do not deal at all with enrichment and implementation of learning innovations.

Daily school practices have shown that bringing innovations from the outside - inside from the institutional side as well as from teachers and students, makes us walk more with time.

Research question of the survey was: How much do the educational institutions influence in the implementation of teaching innovations in the classroom? We used some of the basic methods, especially quantitative methods through

\footnotetext{
${ }^{1}$ Musai.B “Mësimdhënia dhe të nxënët ndërveprues", Qendra për arsim demokratik, Tiranë, 2008, f. 11. [ Teaching and interactive learning] 
which we have researched this problem quite significantly in primary education institutions of Municipality of Kamenica.

Meanwhile, as a measure instrument of teachers' attitudes, we have applied the technique of the survey - the questionnaire. As a sample of the survey we took 100 teachers of both, 50 from the urban schools and 50 from the rural schools of th Municipality of Kamenica. From the survey results we concluded that educational institutions of Kamenica deal quite a few with the implementation or enforcement of instructional innovations.

The research objectives were: educational institutions to be informed about the impact of educational innovations as a soothing element to operate in practice, and providing clearer information about the implementation form of innovations in school.

\subsection{Purpose of the study}

It is to contribute to the discussion that is being developed for education reform in our country, encourage responsible institutions to think about and to take concrete proceedings in the reform of the concept, organization, content, tools, forms and working methods in schools and in other institutions that deal with educational work.

The main purpose that led me to deal with this problem is the hypothesis that: Educational Institutions of the Municipality of Kamenica, is misdoubt that pay quite a bit attention to the importance in implementation of innovations in their schools. For this reason, I wanted to investigate and verify the implementation of innovations by educational institutions, with a full reason for this paper to have a positive impact to institutions, to give greater importance in the implementation of innovations in school practices.

\subsection{Methodology and research techniques}

During this research we used quantitative methods through which we have researched this problem quite considerably generalizing and analyzing the paper about the impact of institutions on the implementation of innovations as an operative element in practice.

From the survey data, we compared the numerical results obtained between elementary schools of Municipality of Kamenica taking into account the comparison of teachers of the urban schools with those in rural areas about the impact of educational institutions in the implementation of innovations as an operative element in practice. And finally we have presented data collected from the respondents (teachers).

To come more easily to research data, we have used the questionnaire for the teachers mentioned above, as a technical procedure to measure the teachers' attitude connected with the reports of the impact of educational institutions in the implementation of innovations in school -class.

Population of this problem consists of all primary school teachers of Municipality of Kamenica, but, since in these schools the same school practice is treated, therefore, have not seen considerable for all teachers to be surveyed, and for this reason, we have studied this problem through the sample.

Our selected sample consisted of a total of 100 teachers divided into two groups, of which one group was from the city, and the other from villages. City group consisted of 50 teachers of the elementary school: "Fan S. Noli "Kamenica. The second group also consisted of 50 teachers of the two elementary schools, such as: (PMLS)

"Skënderbeu" in Hogosht and" Rexhep Malaj " in Topanica.

\section{Analysis and Interpretation of Survey Results}

Between different social environments, there may be differences in terms of work, learning and academic success in general, and at the same time regarding the degree of implementation of innovations by the educational institutions in teaching practices. Therefore, this time we intend to know how much educational institutions have affected the organization and creation of conditions to implement the introduction of innovations in educational practices and what were teachers' thoughts about this issue.

This kind of description enabled us to gain real knowledge about our schools commitment to the implementation of innovations in teaching.

On the first question: Does your institution possess any working strategy for the introduction innovations in school- classroom? Of the 100 teachers that were involved in the research, $4 \%$ by urban area, stated that their schools possess enough working strategy about the introduction of innovations at the school, also from rural area $4 \%$ responded the same. Therefore, $62 \%$ of urban areas and $60 \%$ rural areas stated that their schools possess somewhat working 
strategy, but the differences between them were $2 \%$. While $34 \%$ of the urban area stated that related to these strategies we do not know anything, and from the rural area $36 \%$, so the differences were $2 \%$, which means that most of the teachers of the two areas, about these strategies, almost gave the same opinion stating that the schools where they work, do not possess sufficient working strategy about the introduction of innovations in teaching.
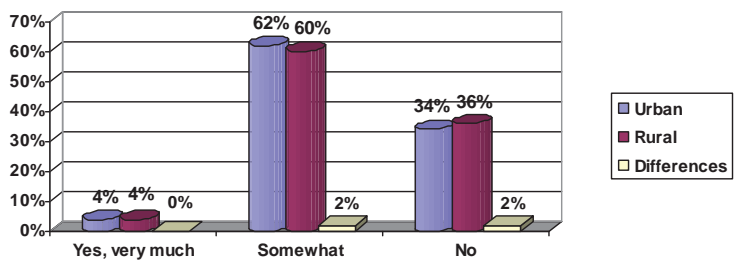

Graph no. 1. Attitudes and differences of teachers from the two area related to institutional strategies over the introduction of innovations in school - classroom

In the question: Do your school institutions have ever required for the introduction of innovation in teaching? Of the 100 teachers involved in the research from the two areas, $8 \%$ of the urban area declared that our institutions have asked us to introduce innovations in teaching, while those of rural areas were $6 \%$. Differences in this response between these two areas were $2 \%$. Whereas, $12 \%$ of the urban area and $16 \%$ of the rural area, have stated that educational institutions rarely require the introduction of innovations in teaching, and the differences were $4 \%$, while $80 \%$ of the urban are stated that educational institutions never require the introduction of innovations in teaching, while form the rural area declared $78 \%$ of them, the differences were $2 \%$. From this we understand that the attitudes and differences of the two school areas related to institutions requirements about introducing innovations in teaching, were almost extinguished, or with no interest at all to make such a request.
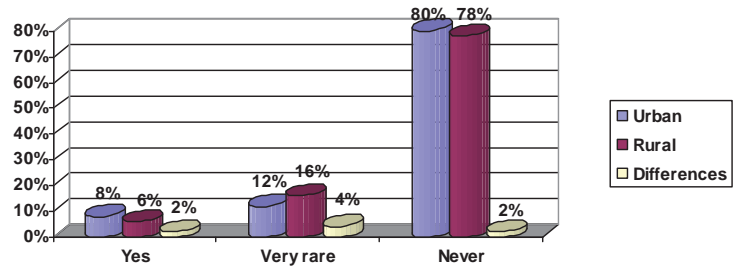

Graph no. 2. Attitudes and differences of teachers of the two areas related to the requirement of educational institutions about the introduction of innovations in teaching.

In the question: Do you think that educational institutions should engage more in introducing innovations in teaching? Of the 100 teachers involved in the research, 50\% of the urban area had stated that educational institutions should engaged more in the introduction of innovations in teaching, whereas $54 \%$ of the rural area has responded the same, while the differences were only $4 \%$.

Therefore, $42 \%$ of the urban are and $44 \%$ of rural area, had stated that there is no need to expect always just from educational institutions, while their differences were $2 \%$. For this matter, $8 \%$ of the urban area and $2 \%$ of rural area denied completely, but the differences were $6 \%$.

From these very similar teachers' statements of the two areas, it is clear that educational institutions are required to engage more about introducing innovations in teaching, but is not expected only from educational institutions. 



Graph no. 3. Attitudes and differences of teachers of the two areas related to their commitment to introducing innovations in teaching.

In the following question: Do you think that educational institutions are obliged to bringing innovations in school learningclassroom? Of the 100 teachers involved in the research, 48\% of the urban area has declared that educational institutions are obliged to bringing innovations in school learning - classroom, while $42 \%$ of the rural areas answered this question, and the differences were $6 \%$.Therefore, 34\% of the urban area and $36 \%$ of the rural area, stated that institutions are partially obliged to do so, and the differences between them were $2 \%$.

While $18 \%$ of the urban area stated that school institutions are not obliged, as while $22 \%$ of the rural area had declared so, and differences were $4 \%$, which means that we are dealing with that educational institutions are obliged for this, but it does not mean that others are not.

Çka do te thotë se, këtu kemi të bëjmë me atë se institucionet shkollore janë të obliguara për këtë, por nuk do të thotë se të tjerëve nuk ju takon.
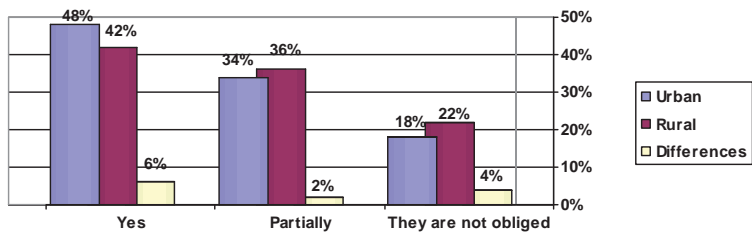

Graph no. 4. Attitudes and differences of teachers related to institutional obligations abort bringing innovations in teaching.

In the last question: Do you need institutional support that will give you help in the implementation of educational innovations in school and classroom? Of the 100 teachers involved in the research, $84 \%$ of the urban area and $92 \%$ of rural area stated that we need institutional support in the implementation of educational innovations, and their differences were $8 \%$.

Therefore, $10 \%$ of the urban area and $4 \%$ of the rural area had stated that we do not need much support, but their differences were $6 \%$. Whereas $6 \%$ of the urban area had declared no, and $4 \%$ of the rural declared so, and the differences were $2 \%$. From these very similar statements of teachers to the two areas, it is clear that the majority of them think that they need institutional support on the implementation of teaching innovation.
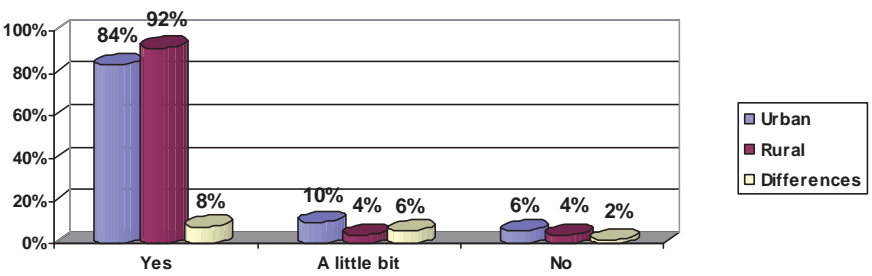

Graph no. 5. Attitudes and differences of teachers of the to areas related to institutional support in implementation of teaching innovations. 


\section{Conclusion}

Needs to investigate and change the situation in education, in the framework of our education system, have recently been closer to the tendency for the advancement of the primary education.

Most teachers both areas on these strategies almost have given the same opinion stating that schools where they work do not possess sufficient and do not organize strategy work about the introduction of innovations in teaching. From this we understand that very few educational institutions are concerned to work and require teachers in implementing innovations in teaching, which means that educational institutions have little or no knowledge about implementation and their importance in practice. Therefore, from the results obtained it is clear that the teachers of the two school areas are seeking from the educational institutions the introduction and the practice of innovations in teaching. But that does not always mean we should expect something new only from educational institutions, but it should happen also by others, as by school administrators, community, student, and especially by the teacher.

Regarding this problem institutional support should be more active and always primarily about cooperation, understanding and interest to make teaching more interesting, more attractive and more fun.

Based on the research data we observe that our educational institutions care very little about the organization of the introduction of innovations in the learning process.

Although teachers are aware that educational institutions are being quite a few interested in this matter, they are still likely to introduce innovations in the learning process seeing reasonable that they can positively influence students' increasing interest for a discussion and practical action classroom.

However, teachers have understood that innovations are necessary for a modern school, but a part of them are still questionable because very few are supported, encouraged or supported by institutions.

Attitudes and differences between the two school areas were almost roughly similar, because of the fact that survey shows that: As urban schools, as well as rural schools, have given approximately the same opinion in the question of non institutional support on the implementation of innovations in school practices.

Regarding teachers' attitudes and differences of the two elementary schools of the two school areas of Municipality of Kamenica, regarding their opinions about the organization and implementation of innovations in the learning process, educational institutions have to take a step more quickly about the positive changes that must happen quickly if we want to move in the right direction.

\section{Recommendations}

Based on the final analysis of this research, we are obliged to propose some of the proceedings that we think educational institutions should run, which would be beneficial to the students, school and society in general. Therefore, the results of this research we have issued the following recommendations:

- To implement innovations from all school subjects.

- To raise the initiatives by relevant institutions in agreement with faculties of education for perfection in order to ensure the systematic training of teachers in addition to undergo changes in the education system.

- To fortify the schools with new techniques and instructional technology, providing the global network, the Internet, to reach quickly the new information.

- To implement new work strategies, that would bring favourable success in comparison with the traditional teaching.

- To harmonize innovation in relation to learning contents by creating a more sprightly and diverse classroom in order the learning process to be more attractive to students.

\section{References}

Andrilovič, V. Čudina, M., Psihologija učenja i nastave, Školska knjiga, Zagreb, 1991.

Bekteshi, Dr. Bektesh, Mbingarkimi i nxënësve me mësim në shkollë, Grafoprint, Prishtinë, 2009.

Bogičevič, Mladen, Tehnologija savremene nastave, Prosveta, Beograd, 1974.

Brada, Dr. Riza, Didaktika kibernetike, Dukagjini, Prishtinë, 2010.

Djordjevič, Dr. Jovan, Savremena nastava i kompjuteri, Nastava i vaspitanje, Beograd, 1987.

Fullan, Majkëll, Kuptimi i ri i ndryshimit në arsim, Qendra për arsim demokratik, Tiranë, 2010.

Ismaili, Xhafer, Në kërkim të njohjes dhe kërkimit të stresit, Libri shkollor, Prishtinë, 2006.

Juniku, Dr. Neki, Modifikimi i sjelljes në shkollë, ETTMK, Prishtinë, 1997 
Karpati, Dr. Andrea; Mollnar, Dr. Gjengjver, Škola budučnosti,Cigoja, Beograd, 2010.

Mandič, Dr. Petar, Novacionet në mësim, ETMM, Prishtinë, 1985.

Mirčeta, Danilovič, Savremena obrazovna tehnologija, Beograd, 1996.

Miroslava, Ristič, obrazovanje na dalin putem interneta, inovacije u nastavu, nr. 3, Beograd, 2000.

Musai, Bardhyl, Mësimdhënia dhe të nxënit ndërveprues, Qendra për arsim demokratik, Tiranë, 2008.

Polak, Vladimir, Didaktičke inovacije i pedagoške reforma kole, Školska knjiga, 1984

Šoljan, Nikola, Tehnologija obrazovanja, Školska knjiga, Zagreb, 1976.

Vilotijevič, Goran, Kako odabrati informacije sa elektroničke mreže, nr. 3, Beograd, 2000.

Vilotijevič, M., Zavod za učbenike, Cigoja, Beograd, 1998. 